\title{
PENGEMBANGAN KREATIVITAS USAHA KAFÉ TENDA DAN WARUNG LESEHAN MELALUI PELAYANAN PRIMA SEBAGAI UPAYA BERWIRASWASTA UNTUK MENGATASI PENGANGGURAN DI KOTA MALANG \\ Tristiadi Ardi Ardani
}

\begin{abstract}
Background: One of phenomenon that can be seen in Malang town, especially in the night, through the Veteran Street, we see many tent café and lesehan stalls. The same thing we meet also in Sunday morning around Gajayana Stadium. The good management will have significant impact to the income of merchants. However, tent cafes and lesehan stalls are still managed traditionally, simple, and unpretentious.

Method: this research is qualitative, that is research conducted by collecting data from informants (interview) and observation, also documentation. This research makes interview to the owner of tent cafes about how they serve consumers. This research works during at least two mounts.

Result: they serve consumers in a simple way and it is not professionally. So that it is important to give best service (prima service) for the consumers to increase their income. Because, in philosophy of business is known that customers or consumers do not only buy product but also the service.

Conclusion: entrepreneur means creating employment for our self and others, to get income for fulfilling the requirement of life.

Prima service pays attention to customer as unique and interesting person, which deserves to get the best and satisfied service. Giving prima service to customer has a purpose to win competition in a business.
\end{abstract}

Keywords: creativity, prima service, entrepreneur, and unemployment.

Krisis multidimensi yang terjadi di Indonesia melanda di berbagai sektor tidak terkecuali di bidang ekonomi yang banyak mengakibatkan jatuhnya suatu perusahaan. Perusahaan publik yang bangkrut mengakibatkan banyaknya pemutusan hubungan kerja (PHK) ribuan pekerja yang mengakibatkan pengangguran semakin bertambah, belum lagi seiring dengan bertambahnya lulusan suatu perguruan tinggi di Indonesia semakin menambah angka pengguran terdidik di negeri yang kita cintai ini.

Wiraswasta merupakan kata kunci yang harus dilakukan untuk mengatasi persoalan di atas. Dengan demikian menjadi wiraswasta tidak lain menciptakan lapangan kerja baru bagi diri sendiri dan bagi orang lain yang bekerja dengan kita.

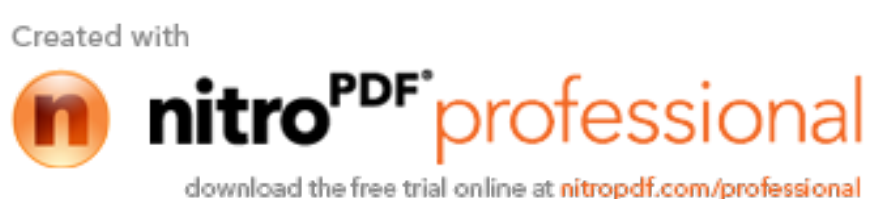


Salah satu fenomena yang terjadi di kota Malang, khususnya di malam hari sepanjang Jalan Veteran banyak kita jumpai warung-warung tenda ataupun warung lesehan yang berderet-derat dengan lampu tradisional yang ada. Selain itu juga banyak kita jumpai di pagi hari di hari minggu di sekitar Stadion Gajayana kafe tenda atau warung lesehan, dan juga juga kita jumpai ditempat lainnya di kota Malang. Animo masyarakat Malang yang sangat tinggi mempunyai dampak yang berarti bagi penghasilan para pedagang tersebut, tetapi seiring dengan menjamurnya kafe tenda dan warung-warung lesehan masih dikelola secara tradisional, sederhana dan terkesan ala kadarnya.

Untuk memberikan kepuasan bagi pelanggan kafe tenda dan warung lesehan perlu di tingkatkan pelayanannya melalui pelayanan prima dan kreatifitas usahanya.

Dalam konteks pemberdayaan sumber daya manusia agar menghasilkan karyawan yang profesional dengan integritas tinggi diperlukan adanya acuan atau sistem pelayanan yang diberlakukan disuatu kafe tenda dan warung lesehan .Menurut peneliti, inti dari pengembangan kreatifitas dari suatu kafe atau warung tenda sangat tergantung kepada faktor sumber daya manusianya (SDM) maka wujud dari kegiatannya adalah pelayanan di seluruh bidang usahanya.

Beranjak pada dasar pemikiran diatas, maka penelitian yang diselenggarakan oleh Lembaga Pengabdian Masyarakat ini difokuskan pada "PENGEMBANGAN KREATIVITAS USAHA KAFÉ TENDA DAN WARUNG LESEHAN MELALUI PELAYANAN PRIMA SEBAGAI UPAYA BERWIRASWASTA UNTUK MENGATASI PENGANGGURAN DI KOTA MALANG"

Penelitian ini bertujuan untuk melihat pengembangan kreativitas usaha kafe tenda dan warung lesehan melalui pelayanan prima sebagai upaya berwiraswasta untuk mengatasi pengangguran. Melalui penelitian ini diharapkan dapat dibuktikan bahwa dengan pelayanan prima berpengaruh pada peningkatan pelanggan pada usaha kafe tenda dan warung lesehan.

Secara teoritis penelitian ini memberikan tambahan kajian tentang berwiraswasta dalam kajian ilmu psikologi khususnya tentang strategi pelayanan prima pada kafe-kafe dan warung lesehan. Secara praktis, memberikan tambahan khasanah acuan tentang pengembangan kreatifitas dan pelayan prima di dunia usaha,dan juga memberikan tambahan informasi bagi praktisi dan pelaku bisnis guna memajukan wirausahanya,selain itu juga memberikan masukan buat pemerintah dan pihak-pihak yang terkait lainnya.

\section{TINJAUAN PUSTAKA}

\section{Kota Malang}

Malang merupakan sebuah kerajaan yang berpusat di kawasan Dinoyo, dengan rajanya Gajayana. Tahun 1767 kompeni menduduki kota, dan tahun 1821 kedudukan pemerintah Belanda dipusatkan di sekitar kali Brantas. Tahun 1821 Malang mempunyai Asisten Residen dan tahun 1882 rumah-rumah dibagian Barat kota didirikan dan Alun-alun dibangun. 
Kota Malang tahun 1914 ditetapkan sebagai kotapraja, dan tanggal 8 Maret 1942 diduduki Jepang. Tanggal 21 September 1945 Malang masuk sebagai wilayah Republik Indonesia. Tanggal 22 Juli Malang diduduki Belanda.

Perkembangan kota Malang tidak terlepas pasang-surut perkembangan kehidupan sosial-budaya, ekonomi, dan politik yang melatar belakanginya. Dari catatan sejarah kota Malang (50-tahun kotapraja Malang), disebutkan bahwa di Malang pernah ada kerajaan Kanjuruhan pada abad ke-VIII , hal ini diketahui dari diketemukannya prasasti Dinoyo yang berangka tahun 682 caka (Nayana Vasurasa). pengaruh- pengaruh kerajaan besar di Jawa seperti Madjapahit dan Mataram juga memberikan peran dalam perkembangan Kota Malang.

Sebelum pemerintahan Belanda masuk kota Malang (1767), Malang dipimpin oleh Adipati Moloyo Kusumo. Setelah Belanda menguasi Malang, kemudian mendirikan pertahanan di sekitar kali Brantas yang selanjutnya mulai membangun Loge (lodji) sebagai tempat tinggal orang Balanda, sehingga daerah tersebut dikenal dengan nama "Klodjen", dari kata "Kalodjian".

Pada awal pendudukan Belanda, masyarakat Eropa (Belanda) pada waktu itu masih tinggal di dalam benteng demi pertimbangan keamanan. Dengan semakin berkembangnya daerah Malang serta makin kuatnya kekuasaan Balanda di Malang maka pada tahun 1824 Malang memiliki Asisten Residen, hal ini berdampak semakin menyempitnya kekuasaan Bupati (adipati).

Mulai 1 April 1914 Malang ditetapkan menjadi Kotapradja dengan residen J.C Hoffman. Tujuan utama penetapan kotapradja Malang adalah menjamin tempat kehidupan yang baik, sehat dan menarik bagi masyarakat Eropa (Belanda), sehingga praktis semua kebijaksanaan pengembangan kota ditujukan bagi kepentingan masyarakat Belanda. Memang perkembangan kota Malang menjadi pesat (lihat analisa stadia perkembangan) perkembangan ini juga berdampak pada pertambahan penduduk Malang, sebagai gambaran pada tahun 1914 penduduk Malang 46.500 (pribumi: 40.000, Asing Asia: 4.000, Eropa: 2.500 orang), pada tahun 1942 penduduk Malang mencapai 22.014 (pribumi: 178.257, asia: 24.372, Eropa: 9.385 mengalami penurunan dari 13.869 pada tahun 1940).

Dengan ditetapkannya Malang menjadi Kotapradja pembangunan kota semakin pesat, Pengadaan waterlaideng, aniem (listrik), pengembangan sarana perhubungan (kereta api sejak 1819) "Malang Stoomtram Maatschappij", Hotel, Rumah sakit Malangsezieken verpleging" (sekarang lavalette dan Soepraoen) dan sebagainya. Akan tetapi kesemuanya terutama untuk kepentingan masyarakat Belanda sedangkan bagi masyarakat "bumiputra" hanya kalangan tertentu saja yang dapat memanfaatkannya.

Dengan ditetapkan menjadi kotapradja, praktis kedudukan bupati menjadi sempit bahkan dibatasi hanya mengurus orang "bumiputra", Keadaan demikian memang diciptakan oleh Belanda. Demikan halnya dengan pusat pemerintahan, pusat kota yang sebelumnya di Alun-alun dialihkan untuk mengurangi kewibawaan bupati dengan menciptakan "alun-alun bunder" sebagai tandingan, dengan Balaikota sebagai pusatnya. 
Rencana kota Malang 1920, yang dibuat oleh Ir Thomas Kartsen, merupakan fenomena baru bagi perencanaan kota-kota di Indonesia, kaidah-kaidah perencanaan modern telah memberikan warna baru bagi bentuk tata ruang kota, seperti penggunaan pola boullevard, bentuk-bentuk simetri yang menonjol dan sangat disukai pada periode renaisance.

Pengembangan kawasan pusat kota dengan banguan bergaya Art deco, munculnya bangunan "sudut" seperti di perempatan PLN, dan bangunan "kembar" di perempatan Kayutangan serta hadirnya bangunan-bangunan bermenara menandai era baru arsitektur perkotaan di Malang.

Bentuk dan tata ruang pusat kota yang terbentuk pada masa pemerintahan Belanda, yang lebih ditujukan bagi kepentingan politis pemerintahan belanda (mengutamakan masyarakat Belanda), ternyata telah menghasilkan bentukan morfologi kota yang cenderung meniru bentuk-bentuk arsitektur gaya Eropa (baca:barat) seperti Art Deco, Renaisance, Baroqe dan sebagainya. Dalam konteks historis sebenarnya keberadaan bangunan peninggalan Belanda merupakan potensi (asset) yang dapat dikembangkan bagi perkembangan arsitektur kota Malang. Melalui aturan-aturan "produk" kolonial, ternyata telah memberikan "warna" pada bentukan fisik lingkungan baik gaya arsitektur maupun pola-pola tata ruang yang terbentuk.

Bentuk morfologi kawasan tercermin pada pola tata ruang, bentuk arsitektur bangunan, serta elemen-elemen fisik kota lainnya pada keseluruhan konteks perkembangan kota. Perkembangan selanjutnya, kekuatan domain ekonomi, sebagai akibat cepatnya pertumbuhan ekonomi telah membawa implikasi perubahan pada karakter dan bentuk morfologi kawasan pusat kota Malang. Disisi lain, pengendalian perkembangan kawasan pusat kota tidak memperhatikan konteks kesejarahan pembentukan kota, sehingga seperti halnya kota besar lainnya, kota Malang-pun mempunyai kecenderungan kehilangan karakter spesifiknya dan muncul karakter "ketunggal rupaan" arsitektur kota (Eko Budiardjo,1982), sehingga kesinambungan kesejarahan kawasan seolah terputus sebagai akibat pengendalian perkembangan yang kurang memperhatikan aspek morfologis kawasan.

Kota Malang memiliki luas $124.456 \mathrm{Km}$. persegi, dihuni oleh 700.000 warganya. Kepadatan penduduk mencapai 5.000 - 12.000 jiwa per kilometer persegi dengan tingkat pertumbuhan $3.9 \%$ per tahun. Tersebar di 5 Kecamatan (Klojen, Blimbing, Kedungkandang, Sukun dan Lowokwaru), 47 Kelurahan, 10 Desa, 442 RW dan3.208RT

Etnik Masyarakat Malang terkenal religius, dinamis, suka bekerja keras, lugas dan bangga dengan identitasnya sebagai Arek Malang (AREMA). Komposisi penduduk asli berasal dari berbagai etnik (terutama suku Jawa, Madura, sebagian kecil keturunan Arab dan Cina)

Masyarakat Malang sebagian besar adalah pemeluk Islam kemudian Kristen, Katolik dan sebagian kecil Hindu dan Budha. Umat beragama di Kota Malang terkenal rukun dan saling bekerja sama dalam memajukan Kotanya. Bangunan tempat ibadah banyak yang telah berdiri semenjak jaman kolonial antara lain Masjid Jami (Masjid Agung), Gereja (Alun2, Kayutangan dan Ijen) serta Klenteng di Kota Lama. 
Malang juga menjadi pusat pendidikan keagamaan dengan banyaknya Pesantren dan Seminari Alkitab yang sudah terkenal di seluruh Nusantara

Kekayaan etnik dan budaya yang dimiliki Kota Malang berpengaruh terhadap kesenian tradisonal yang ada. Salah satunya yang terkenal adalah Tari Topeng, namun kini semakin terkikis oleh kesenian modern. Gaya kesenian ini adalah wujud pertemuan gaya kesenian Jawa Tengahan (Solo, Yogya), Jawa Timur-Selatan (Ponorogo, Tulungagung, Blitar) dan gaya kesenian Blambangan (Pasuruan, Probolinggo, Situbondo, Banyuwangi).

Bahasa Jawa dialek Jawa Timuran dan bahasa Madura adalah bahasa seharihari masyarakat Malang. Dikalangan generasi muda berlaku dialek khas Malang yang disebut 'boso walikan' yaitu cara pengucapan kata secara terbalik, contohnya : seperti Malang menjadi Ngalam. Gaya bahasa di Malang terkenal kaku tanpa unggah-ungguh sebagaimana bahasa Jawa kasar umumnya. Hal menunjukkan sikap masyarakatnya yang tegas, lugas dan tidak mengenal basa-basi.

Kebanyakan pendatang adalah pedagang, pekerja dan pelajar / mahasiswa yang tidak menetap dan dalam kurun waktu tertentu kembali ke daerah asalnya. Sebagian besar berasal dari wilayah disekitar Kota Malang untuk golongan pedagang dan pekerja. Sedang untuk golongan pelajar / mahasiswa banyak yang berasal dari luar daerah (terutama wilayah Indonesia Timur) seperti Bali, Nusa Tenggara, Timor Timur, Irian Jaya, Maluku, Sulawesi dan Kalimantan.

\section{Kreativitas}

Kreativitas adalah kemampuan untuk menciptakan atau menghasilkan sesuatu yang baru. hasil karya atau ide-ide baru itu sebelumnya tidak dikenal oleh pembuatnya maupun orang lain. Kemampuan ini merupakan aktivitas imajinatif yang hasilnya merupakan pembentukan kombinasi dari informasi yang diperoleh dari pengalaman-pengalaman sebelumnya menjadi hal yang baru, berarti dan bermanfaat. Amabile dkk sebagaimana dikutip Utami Munandar mengartikan kreativitas sebagai produksi suatu respons atau karya yang baru dan sesuai dengan tugas yang dihadapi.

Sementara itu, Bobbi DePorter dan Mike Hernacki mengartikan kreativitas sebagai"......melihat hal yang dilihat orang lain, tapi memikirkan hal yang tidak dipikirkan orang lain."

Amabile dkk melihat kreativitas dari produknya, sementara Renzulli, De Porter dan Hernacki, serta Guilford memandang dari prosesnya.

Guilford (1982) ${ }^{1}$ menemukan bahwa faktor penting yang merupakan ciri dari kemampuan berpikir kreatif ialah, pertama, kelancaran berpikir (fluency of thinking), yaitu kemampuan untuk menghasilkan banyak ide yang keluar dari pemikiran seseorang secara cepat. Kedua, keluwesan (flexibility), yaitu kemampuan untuk memproduksi sejumlah ide, jawaban-jawaban atau pertanyaan-pertanyaan yang bervariasi. Ketiga, elaborasi (elaboration), yaitu kemampuan dalam mengembangkan gagasan dan menambahkan atau memperinci detil-detil dari suatu objek, gagasan atau situasi sehingga menjadi lebih menarik. Keempat, keaslian (originality), yaitu 
kemampuan untuk mencetuskan gagasan unik (unusual) atau kemampuan untuk mencetuskan gagasan asli.

Menurut David Campbell $(1990)^{2}$ mengungkapkan bahwa tahapan-tahapan tersebut meliputi, Pertama, tahap persiapan. Pada periode ini individu meletakkan dasar pemikiran, menyatakan masalah dan mengumpulkan materi-materi yang diperlukan untuk pemecahan masalah. Kedua, tahap konsentrasi. Perhatian individu tercurah dan pikiran individu unidividu terpusat pada hal-hal yang mereka kerjakan. Ketiga, tahap inkubasi. Individu seolah-olah melepaskan diri untuk sementara dari masalah yang dihadapi atau tidak memikirkan secara sadar, tetapi menyimpannya dalam alam pra sadar. Keempat tahap penerangan. Hasil kreatif baru muncul pada periode ini, individu mengalami insight, ide untuk pemecahan masalah muncul secara tiba-tiba dan diikuti perasaan senang. Kelima tahap pembuktian (verification) pada tahap ini individu mengekspresikan ide-idenya dalam bentuk nyata.

Faktor-faktor yang mempengaruhi kreativitas menurutm Utami Munandar terdir dari aspek kognitif dan aspek kepribadian. Faktor kemampuan berpikir terdiri dari kecerdasan (inteligensi) dan pemerkayaan bahan berpikir berupa pengalaman dan ketrampilan. Faktor kepribadian terdiri dari rasa ingin tahu, harga diri dan kepercayaan diri, sifat mandiri, berani mengambil resiko dan asertif, tipe kepribadian

\section{Pelayanan Prima}

Bangsa Indonesia terkenal akan keramahan dan kehangatan yang tulus dalam bernegosiasi, selain memiliki keuletan, keprihatinan, dan kesabaran yang tinggi dalam berusaha. Pada hakekatnya pelanggan itu tidak membeli produk, tapi mereka membeli pelayanan. Ini merupakan falsafah bisnis dalam memberikan pelayanan yang prima.

Beberapa pendapat mengenai arti pentingnya pelayanan ini terlihat dari pengertian palayanan menurut beberapa ahli yaitu:

Menurut Hadipranata( dalam Moeljono, 2001) ${ }^{3}$ berpendapat bahwa pelayanan adalah aktifitas tambahan di luar tugas pokok (job description) yang diberikan pada konsumen: pelanggan, nasabah, pengunjung dan sebagainya, serta dirasakan sebagai penghargaan maupun penghormatan.

Menurut Sugiarto (1999) ${ }^{4}$ pada dasarnya yang dimaksud dengan layanan prima (customer care) adalah kemampuan maksimal seseorang dalam berhubungan dengan orang lain dalam hal pelayanan. Memberikan pelayanan prima kepada pelanggan mempunyai tujuan untuk memenangkan persaingan. Layanan prima sangat memperhatikan individu sebagai pribadi yang unik dan menarik. Setiap pelanggan memiliki sifat yang dapat membuat petugas bahagia atau kecewa. Sentuhan pribadi mengarahkan para petugas palyanan untuk berfikir bahwa memperlakukan orang lain sebagaimana kita memperlakukan diri kita sendiri perlu selalu dipraktekkan. 
Kewajiban untuk menghormati orang lain dijelaskan oleh Hadripranata dalam kumpulan kuliahnya ( 1999$)^{5}$ mengenai keyakinan orang Jepang terhadap pentingnya menghormati orang lain dalam bentuk pelayanan dalam KAIZEN yang berbunyi: "Tsungi tsungi no bubun wa watakushi no okyakusuma. Okyakusuma wa Kamisama deshoo". Artinya: Sebelah menyebelahlah saya adalah tamu-tamu saya yang harus saya hormati sebagaimana "Tuhan".

Menurut Hadripranata, pada saat ditanyakan kepada orang Jepang apa yang melatarbelakangi atau memberikan inspirasi ditemukan kredo yang begitu menyentuh dijawab bahwa sumbernya adalah ayat suci

"Dan apabila kamu diberi penghormatan dengan suatu penghormatan, maka balaslah penghormatan itu dengan yang lebih baik dari padanya, atau hendaklah kamu membalasnya ( dengan yang sepadan ), sesungguhnya Allah atas segala sesuatu Maha memperhitungkan". (QS. Al-Nisa', 86)

komunikasi:

Konsep pribadi meliputi unsur-unsur kepribadian, penampilan, perilaku, dan

a. Pribadi Prima tampil ramah

b. Pribadi Prima tampil sopan dan penuh hormat

c. Pribadi Prima tampil yakin

d. Pribadi Prima tampil rapi

e. Pribadi Prima tampil ceria

f. Pribadi Prima senang memaafkan

g. Pribadi Prima senang bergaul

h. Pribadi Prima senang belajar dari orang lain

i. Pribadi Prima senang pada kewajaran

j. Pribadi Prima senang menyenangkan orang lain

Metode pelatihan peyanan prima mengarahkan anda untuk melakukan pelatihan mandiri. Bentuk pelatihan interaksi dengan pelanggan secara langsung meliputi:

- Pelayanan normal ( dasar)

- Melayani lebih dari seorang pelanggan pada saat bersamaan

- Melayani pelayanan yang tertunda

- Melayani pembayaran yang bermasalah

- Melayani pemesanan

- Melayani pelanggan yang tidak sabar

- Melayani transaksi pembayaran

- Melayani pelayanan yang tidak dapat diberikan

- Melayani pembatalan pemesanan

- Melayani tamu yang banyak permintaan

\section{Wiraswasta}

Wiraswasta artinya mampu dan berani menciptakan lapangan kerja bagi diri sendiri dan orang lain, yang bertujuan mencari penghasilan untuk memenuhi 
kebutuhan hidup sendiri dan masyarakat pada umumnya.Wiraswasta sebagai manusia unggul seharusnya memiliki sifat-sifat ideal sebagai berikut:

- Budi luhur, sabar, tabah

- Berani, kemauan keras,jujur

- Adil, simpatik, komunikatif

- Tekun, inovatif, empatik, , rendah hati

- Ulet, jeli, positif, kreatif

\section{METODE}

Jenis penelitian yang digunakan dalam penulisan laporan ini adalah penelitian kualitatif, yaitu penelitian yang dilakukan dengan mengumpulkan data yang terbentuk kata-kata atau kalimat dari informan yang ada di dala penelitian.

\section{Jenis Fakta/Data}

Mengingat penelitian ini termasuk penelitian kualitatif, maka data yang dibutuhkan juga bersifat kualitatif yakni data yang berhubungan dengan kata-kata atau kalimat. Keterangan atau penjelasan-penjelasan mengenai perasaan dan tingkah laku subyek dalam hubungan dengan fokus masalah yang diteliti.

Pengembangan kreativitas usaha kafe tenda dan warung lesehan melalui pelayanan prima sebagai upaya berwiraswasta untuk mengatasi pengangguran. Melalui penelitian ini diharapkan dapat dibuktikan bahwa dengan pelayanan prima berpengaruh pada peningkatan pelanggan pada usaha kafe tenda dan warung lesehan.

\section{Sumber dan Teknik Pengumpulan Data}

Sumber data adalah hal-hal yang menunjukkan darimana data yang dibutuhkan dapat diperoleh baik berupa orang (informan) maupun dari sumbersumber lain. Dari sumber data tersebut maka yang menjadi sumber primer dalam penelitian ini adalah.pemilik warung tenda dan warung lesehan di kota Malang

Banyak teknik yang digunakan dalam pengumpulan suatu data tetapi yang digunakan dalam penelitian ini hanya dua teknik, yaitu:

a. Teknik observasi,

b. Teknik wawancara,

\section{Instrumen Penelitian}

Penelitian merupakan instrumen utama dalam penelitian ini (sesuai dengan karakteristik penelitian kualitatif itu sendiri). Dalam penelitian , peneliti sendiri yang akan terjun langsung ke site penelitian selaku " tangan pertama " ; tidak digunakan tenaga pengumpul data di luar peneliti. I

Instrumen lain yang digunakan adalah blanko dokumentasi untuk merekam data sekunder / dokumentasi yang tersedia tentang café tenda dan warung lesehan di Malang.

\section{PROSEDUR PENGUMPULAN DATA}

\section{Subjek Penelitian}

Subyek penelitian memiliki karakteristik umum sebagai berikut :

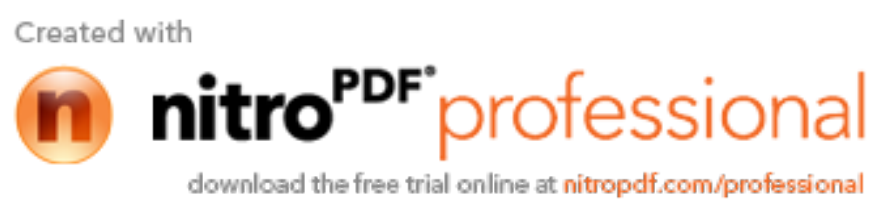


- Warung lesehan

- Café tenda

- Lokasi di Malang

\section{Prosedur Pengumpulan Data}

Kegiatan penelitian sebagai suatu kegiatan yang sistematis maka pelaksanaannya harus mengikuti prosedur tertentu, agar hasilnya dapat dipertanggung jawabkan kebenarannya secara ilmiah. Berangkat dari teknik kedua tersebut di atas maka prosedur pengumpulan data adalah sebagai berikut:

a. Proses Observasi

b. Proses wawancara

\section{Proses Perekaman Data}

Paling tidak ada dua proses yang perlu dilalui dalam perekaman data di lokasi penelitian, kedua proses tersebut adalah sebagai berikut:

a. Perekaman data di lapangan

Semua data yang telah diperoleh atau terekam baik dengan observasi dan wawancara dimasukkan ke dalam catatan lapangan secara rinci dan jelas.

b. Perekaman data setelah observasi lapangan

Dari catatan lapangan yang bersifat sementara atau belum teratur selanjutnya diolah dan dianalisa secara lebih terinci dan mendalam. Dengan demikian akan membantu memudahkan peneliti untuk kelengkapan dan keabsahan data.

\section{ANALISIS DATA}

Rancangan analisa yang digunakan adalah analisa deskriptif yaitu penyusunan hasil penelitian dijabarkan dalam bentuk gambaran penjelasan dan keterangan, terhadap gejala-gejala, maupun fakta yang terkumpul dalam bentuk kata-kata atau kalimat dari latar penelitian.

\section{Sumber Data}

Ada dua sumber data dalam penelitian ini yaitu data primer dan data sekunder. Untuk mendapatkan data primer, peneliti melakukan wawancara mendalam terhadap beberapa informan,. Data sekunder diperoleh melalui sumber literatur, bahan referensi, dan dokumentasi.

\section{Teknik Pengumpulan Data}

Teknik pengumpulan data dalam penelitian ini menggunakan teknik observasi dan wawancara.

\section{Instrumen Penelitian}

Penelitian merupakan instrumen utama dalam penelitian ini (sesuai dengan karakteristik penelitian kualitatif itu sendiri). Dalam penelitian, peneliti sendiri yang akan terjun langsung ke site penelitian selaku " tangan pertama "; tidak digunakan tenaga pengumpul data di luar peneliti. Instrumen lain yang digunakan adalah blanko dokumentasi untuk merekam data sekunder / dokumentasi yang tersedia..

\section{Proses Pengumpulan Data}

Ada tiga elemen utama yang diobservasi yaitu:

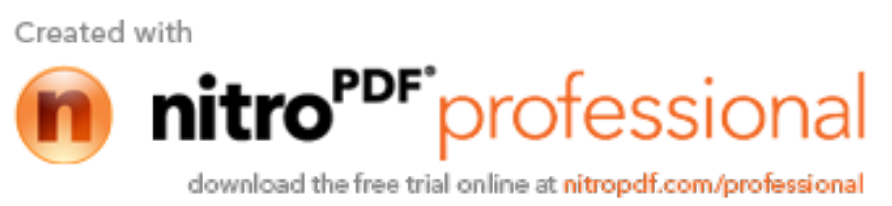


a). Lokasi/fisik tempatkafe tenda dan warung lesehan yang ada di sekitar kota Malang b). Manusia-manusia pelaku atau aktor yang terlibat pengelolaan kafe tenda dan warung lesehan.

c). Kegiatan atau aktivitas para pelaku pada lokasi/tempat kafe tenda dan warung lesehan tersebut.

Wawancara dengan informan dilakukan secara terpisah antara informan yang satu dengan yang lainnya.

Menurut Ardani ( 2004 ) $^{6}$ strategi wawancara yang berhasil didasari oleh suatu usaha untuk berkomunikasi secara jelas dan untuk memahami komunikasi itu yaitu:.

a). Memantapkan Rapport

Rapport didasari oleh saling percaya, respek dan penerimaan. Interviewer bertanggung jawab untuk membuat interviewee melihat interviewer sebagai orang yang dapat dipercaya dan siap membantu. Tujuannya adalah membangun suasana hangat dan penuh penerimaan sehingga interviewee merasa dipahami dan aman, dan mulai berkomunikasi secara terbuka tanpa merasa takut sedang dinilai atau dikritik.

Pemantapan rapport dapat dilakukan dengan menjaga kontak mata; menjaga postur yang alami, santai dan penuh perhatian; berbicara dengan pelan dan jelas dalam sikap yang tenang, lugas, ramah, dan penuh penerimaan; menggunakan nada suara yang hangat dan ekspresif; mendekati interviewee dengan cara yang tidak menilai; dan membuat interview suatu kesempatan berbagi. Respon verbal interviewer harus mencakup tidak hanya komentar interviewee tetapi juga perilaku verbal dan non verbal interviewee. Interviewer tidak boleh menyela interviewee, kecuali jika memang perlu.

b). Menunjukkan Minat

Rapport sangat ditentukan oleh minat yang ditunjukkan oleh interviewer. Interviewee perlu mengetahui bahwa interviewer ingin memahami cara dia memandang dunianya; menghargai pengalamannya, berbagi dalam usahanya untuk mengingat, mengorganisasi, dan mengekspresikan pengalamannya; menghargai kesulitannya dalam mendiskusikan materi pribadi; dan ingin merefleksikan secara tepat pendapat, perasaan, dan keyakinannya. Pernyataan-pernyataan yang menunjukkan minat, perhatian, empati, kepekaan, penghargaan, dan pemahaman perlu disertai dengan perilaku nonverbal yang sesuai.

\section{METODE TRIANGULASI}


Menurut Ardani (2004) ${ }^{7}$ metode triangulasi merupakan salah satu metode yang paling umum dipakai dalam uji validitas dalam penelitian kualitatif. Triangulasi adalah teknik pemeriksaan keabsahan data yang memanfaatkan sesuatu yang lain di luar data itu untuk keperluan pengecekan atau pembanding terhadap data itu

Teknik triangulasi yang paling banyak digunakan adalah pemeriksaan melalui sumber lainnya. Denzin membedakan empat macam triangulasi sebagai teknik pemeriksaan yang memanfaatkan penggunaan sumber, metode, penyidik dan teori. Triangulasi dengan sumber berarti membandingkan dan mengecek balik derajat kepercayaan suatu informasi yang diperoleh melalui waktu dan alat yang berbeda dalam metode kualitatif.

Hal ini dapat dicapai dengan jalan antara lain:

a). Membandingkan data hasil pengamata dengan data hasdl wawancara

b). Membandingkan dengan apa yang dikatakan orang di depan umum dengan apa yang dikatakannya secara pribadi.

c) Membandingkan apa yang dikatakan orang-orang tentang situasi penelitian dengan apa yang dikatakannya sepanjang waktu

d) Membandingkan keadaan dan perspektif seseorang dengan berbagai pendapat dan pandangan orang seperti rakyat biasa, orang yang berpendidikan menengah atau tinggi, orang berada, orang pemerintahan

e) Membandingkan hasil wawancara dengan isi suatu dokumen yang berkaitan.

Pada triangulasi dengan metode, terdapat dua strategi, yaitu

1. Pengecekan derajat kepercayaan penemuan hasil penelitian beberapa teknik pengumpulan data

2. Pengecekan derajat kepercayaan beberapa sumber data dengan metode yang sama.

\section{HASIL DAN PEMBAHASAN}

\section{Persiapan Penelitian}

Lokasi penelitian adalah café tenda atau warung lesehan yang ada di kota

Malang,Mulai di jalan Raya Tlogomas, Jalan Veteran, jalan Sukarno Hatta, dan café tenda minggu di stadion gajayana Malang.

Penelitian merupakan instrumen utama dalam penelitian ini (sesuai dengan karakteristik penelitian kualitatif itu sendiri). Dalam penelitian, peneliti sendiri yang akan terjun langsung ke site penelitian selaku " tangan pertama " ; tidak digunakan tenaga pengumpul data di luar peneliti. Instrumen lain yang digunakan adalah blanko dokumentasi untuk merekam data sekunder / dokumentasi yang tersedia.

\section{Pengumpulan Data}

Penelitian yang dilakukan di akhir tahun 2004 ini , terhadap pemilik café tenda dan warung lesehan tentang pelayanan yang mereka berikan kepada konsumen., penelitian dilakukan selama kurang lebih dua bulan. Dari hasil wawancara dan observasi yang dilakukan terhadap informan maka diperoleh data bahwa lima orang 
responden yang merupakan pemilik café tenda dan warung lesehan di Malang yang menjual STMJ, lalapan, pecel blitar, lesehan ayam bakar, dan café tenda nasi goreng Al-Yalu yang berada di Tlogomas Malang.

Dalam wawancara yang dilakukan bahwa pelayanan yang diberikan masih sekedarnya saja dan terkesan apa adanya, belum ditangani secara profesional yaitu melalui pelayanan prima.

\section{Analisis Data}

Dari hasil data yang dikumpulkan dari informan pemilik café tenda dan warung lesehan yaitu untuk memberikan kepuasan bagi pelanggan kafe tenda dan warung lesehan perlu di tingkatkan pelayanannya melalui pelayanan prima dan kreatifitas usahanya..

Pada hakekatnya pelanggan itu tidak membeli produk, tapi mereka membeli pelayanan. Ini merupakan falsafah bisnis dalam memberikan pelayanan yang prima. Beberapa pendapat mengenai arti pentingnya pelayanan ini terlihat dari pengertian palayanan menurut beberapa ahli yaitu:

Menurut Hadipranata (dalam Moeljono, 2001) ${ }^{8}$ berpendapat bahwa pelayanan adalah aktifitas tambahan di luar tugas pokok ( job description) yang diberikan pada konsumen: pelanggan, nasabah, pengunjung dan sebagainya, serta dirasakan sebagai penghargaan maupun penghormatan.

Menurut Sugiarto ( 1999$)^{9}$ pada dasarnya yang dimaksud dengan layanan prima ( customer care) adalah kemampuan maksimal seseorang dalam berhubungan dengan orang lain dalam hal pelayanan. Memberikan pelayanan prima kepada pelanggan mempunyai tujuan untuk memenangkan persaingan. Layanan prima sangat memperhatikan individu sebagai pribadi yang unik dan menarik. Setiap pelanggan memiliki sifat yang dapat membuat petugas bahagia atau kecewa. Sentuhan pribadi mengarahkan para petugas palyanan untuk berfikir bahwa memperlakukan orang lain sebagaimana kita memperlakukan diri kita sendiri perlu selalu dipraktekkan.

Kewajiban untuk menghormati orang lain dijelaskan oleh Hadripranata dalam kumpulan kuliahnya ( 1999$)^{10}$ mengenai keyakinan orang Jepang terhadap pentingnya menghormati orang lain dalam bentuk pelayanan dalam KAIZEN yang berbunyi: "Tsungi tsungi no bubun wa watakushi no okyakusuma. Okyakusuma wa Kamisama deshoo". Artinya : Sebelah menyebelahlah saya adalah tamu-tamu saya yang harus saya hormati sebagaimana "Tuhan".

Menurut Hadripranata, pada saat ditanyakan kepada orang Jepang apa yang melatarbelakangi atau memberikan inspirasi ditemukan kredo yang begitu menyentuh dijawab bahwa sumbernya adalah kitab suci.

Artinya: "Dan apabila kamu diberi penghormatan dengan suatu penghormatan, maka balaslah penghormatan itu dengan yang lebih baik dari 
padanya, atau hendaklah kamu membalasnya ( dengan yang sepadan ), sesungguhnya Allah atas segala sesuatu Maha memperhitungkan" (QS. Al-Nisa, 86).

\section{KESIMPULAN DAN SARAN}

\section{Kesimpulan}

Wiraswasta artinya mampu dan berani menciptakan lapangan kerja bagi diri sendiri dan orang lain, yang bertujuan mencari penghasilan untuk memenuhi kebutuhan hidup sendiri dan masyarakat pada umumnya.

Memberikan pelayanan prima kepada pelanggan mempunyai tujuan untuk memenangkan persaingan. Layanan prima sangat memperhatikan individu sebagai pribadi yang unik dan menarik. Setiap pelanggan memiliki sifat yang dapat membuat petugas bahagia atau kecewa. Sentuhan pribadi mengarahkan para petugas palyanan untuk berfikir bahwa memperlakukan orang lain sebagaimana kita memperlakukan diri kita sendiri perlu selalu dipraktekkan

\section{Saran}

Kegiatan ini dilakukan oleh lembaga Pengabdian Masyarakat yang otomatis berhubungan secara luas dan bermanfaat bagi masyarakat luas khususnya di kota Malang dan sekitarnya. Pihak pemerintah khususnya yang menangani Unit Kegiatan Masyarakat ( UKM ).

Bagi LPM UIN Malang khususnya peneliti merupakan kegiatan pengabdian di masyrakat. Bagi pemilik kafe dan warung tenda, ini bisa dijadikan masukan yang berarti guna mensejahterakan diri sendiri dan orang lainnya. Bagi pemilik café tenda dan warung tenda perlu adanya pelatihan pelayanan prima.

Teknik dasar pelayanan antara lain:

Ucapkan salam pada pelanggan,Tawarkan bantuan untuk melayani,Layanilah keinginan tamu dengan sebaik-baiknya, Setelah selesai melayani ucapkan terima kasih.

\section{Catatan Akhir:}

1 Guilford, J.P, "Traits of Creativity", dalam P. Vernon (Ed), Creativity, (England, Penguin Education, 1982),

${ }^{2}$ Campbell, D, Mengembangkan Kreativitas, saduran A.M. Mangunhardjana, (Yogyakarta, Kanisius, 1990),

3 Moeljono. D, Focus Group Discussion (Yogyakarta, Desertasi Program Pascasarjana UGM, 2001),

${ }^{4}$ Sugiarto. E, Psikologi Pelayanan Dalam Industri Jasa. (Jakarta, Gramedia Pustaka, 1999),

${ }^{5}$ Hadipranata, A.F, Diktat Kuliah Psikologi Konsumen Untuk Mahasiswa S-2, (Yogyakarta, Program Pascasarjana UGM , 1999),

${ }^{16}$ QS. Al- Nisa, 86 
7 Ardani. T.A dan Rahayu, Observasi dan Wawancara. (Malang, Bayu Media, 2004),

${ }^{8}$ Ibid, 103

${ }^{9}$ Ibid, 20

${ }^{10}$ Ibid, 100

${ }^{11}$ Ibid, 25

\section{DAFTAR PUSTAKA}

Ardani. T.A dan Rahayu. I.R., Observasi dan Wawancara. (Malang, Bayu Media, 2004)

Campbell, D. Mengembangkan Kreativitas. Disadur dari A.M. Mangunhardjana. (Yogyakarta: Kanisius, 1990).

Guilford, J.P. "Traits of Creativity", Dalam P. Vernon (ed), Creativity, (England: Penguin Education, 1982).

Hadipranata, A.F. 1999. Diktat Kuliah Psikologi Konsumen Untuk Mahasiswa S-2, (Yogyakarta, Program Pascasarjana UGM , 1999)

Moeljono. D, Focus Group Discussion,(Yogyakarta, Desertasi Program Pascasarjana UGM, 2001). 